\title{
Белково-полисахаридный имитатор жира для ферментированного молочного продукта
}

\author{
Мельникова Елена Ивановна \\ ФГБОУ ВО «Воронежский государственный университет \\ инженерных технологий» \\ Адрес: 394000, Воронеж, пр. Революции, д. 19 \\ E-mail:melnikova@molvest.ru \\ Станиславская Екатерина Борисовна \\ ФГБОУ ВО «Воронежский государственный университет \\ инженерных технологий» \\ Адрес: 394000, Воронеж, пр. Революции, д. 19 \\ E-mail: tereshkova-katia@yandex.ru \\ Фёдорова Арина Романовна \\ ФГБОУ ВО «Воронежский государственный университет \\ инженерных технологий» \\ Адрес: 394000, Воронеж, пр. Революции, д. 19 \\ E-mail: arina.fiodorova@yandex.ru
}

\begin{abstract}
В данной работе описаны исследования, подтверждающие возможность использования белково-полисахаридного имитатора жира в составе ферментированного молочного продукта. Цель работы - исследование взаимодействия микропартикулятов сывороточных белков и пектинов в составе комплексного имитатора жира в условиях формирования структуры ферментированного молочного продукта. Показатели состава объектов исследования, их физико-химические свойства определяли в соответствии с Российскими стандартами. Добавление пектина увеличивало значение среднего диаметра частиц и вязкости белкового имитатора жира. При смешивании микропартикулята сывороточных белков и пектина наблюдали образование частиц правильной круглой формы с диаметром от 6,2 до 25,3 мкм. Совместная термомеханическая обработка концентрата сывороточных белков и раствора пектина способствовала формированию более крупных частиц неправильной формы. Применение белково-полисахаридных имитаторов жира не оказывало существенного влияния на скорость кислотообразования при сквашивании обезжиренного молока. При внесении в продукт комплексного имитатора, состоящего из смеси микропартикулята сывороточных белков и пектина, частицы белкового компонента выполняли роль неактивного наполнителя. Пектин участвовал в образовании инертных нитей, прочно интегрированных в структуру сгустка. Это повышало прочность и вязкость готового продукта, способствовало снижению синерезиса. Применение имитаторов, полученных при термомеханической обработке смеси концентрата сывороточных белков и раствора пектина, оказывало негативное влияние на характеристику кислотного сгустка. Крупные частицы белково-полисахаридных агрегатов «разрывали» сетчатую структуру, образованную казеиновыми мицеллами, обусловливая формирование слабого геля. Выполненные исследования послужили основой для разработки рецептурно-компонентного решения и технологии ферментированного продукта. Качественные показатели его отвечали требованиям нормативной документации. Энергетическая ценность нового продукта составила 32 ккал/100 г, что характеризует его как низкокалорийный.
\end{abstract}

Ключевые слова: микропартикуляция, пектин, ферментированный продукт, сывороточные белки, степень этерификации, микроструктура, кислотный сгусток.

\section{Введение}

К одной из важных задач в области обеспечения здорового питания населения Российской Федерации относится снижение калорийности пищевых рационов, в частности за счет уменьшения доли насыщенных жиров. Сохранению приемлемых органолептических характеристик низкокалорийных продуктов, обеспечивающих стабильный потребительский спрос, способствует применение 
имитаторов жира. Эти пищевые компоненты позволяют сформировать густую, сливочную консистенцию низкожирных продуктов, приближая их качественные показатели к полножирным. В настоящее время известно несколько групп имитаторов жира. Ингредиенты углеводной природы, представленные низкомолекулярными крахмалами, декстринами, мальтодекстринами, а также синтетические вещества, применяемые для замены жира, при чрезмерном потреблении могут привести к нарушению деятельности желудочно-кишечного тракта. Наиболее приемлемыми являются имитаторы белковой природы, изготовленные на основе молока, яиц. Они не оказывают побочного воздействия на организм человека, повышают биологическую ценность продуктов и снижают их калорийность.

В последние годы большой интерес в качестве имитаторов жира белковой природы приобретает применение микропартикулятов сывороточных белков (Евдокимов и др., 2021; Phil, 2019). Источником их получения являются ультрафильтрационные концентраты молочной сыворотки, подвергнутые термомеханической обработке (3олотарева, Володин, Евдокимов, Харитонов, 2018). Технология микропартикуляции способствует формированию сферических частиц белка, по форме и размеру схожих с жировыми шариками (Мельникова \& Станиславская, 2017). Применение их не только снижает энергетическую ценность традиционных продуктов питания, сохраняя приемлемые органолептические свойства, но и обогащает белками и аминокислотами, повышая биологическую ценность (Olivares, Shahrivar, \& de Vicente, 2019; Ipsen, 2017). Высокую эффективность показало применение микропартикулятов сывороточных белков в производстве кисломолочных продуктов (йогуртов, кефира, сметаны, творога) и сыра, позволяющее модифицировать их вкусовые и реологические характеристики и увеличивать выход (Баранов, Евдокимов, Гордиенко, \& Шрамко, 2020; Дымар, 2014; Di Cagno et al., 2014; Melnikova, Losev, \& Stanislavskaia, 2017, Torres, Mutaf, Larsen, \& Ipsen, 2016; Torres et al., 2018).

В настоящее время в молочной промышленности для формирования структуры и удлинения сроков годности продукции применяют стабилизаторы консистенции, в частности полисахаридной природы. Они используются в качестве компонентов при производстве йогуртов, молочных десертов, мороженого (Артемова, 2001). К одному из распространенных загустителей, применяемых для получения стабильных пищевых систем, от- носится пектин. Это гетерополисахарид, элементарным звеном которого являются в разной степени метоксилированные остатки D-галактуроновой кислоты. Различное содержание функциональных групп (метоксильных, карбоксильных, гидроксильных), степень деметоксилирования, присутствие примесей оказывает влияние на физико-химические и функциональные свойства пектинов. Гелеобразование в водных средах происходит в результате взаимодействия молекул пектина между собой. Основными факторами, определяющими характер этих взаимодействий в молочных продуктах, являются степень этерификации и диссоциации молекул, а также присутствие других компонентов (Нечаев, Траубенберг, Кочеткова, \& Колпакова, 2015).

Вопросам взаимодействия белков и полисахаридов в составе продуктов питания посвящены многочисленные исследования (Куликова, Барыбина, Оботурова, \& Дацко, 2014; Тешаев, Усманова, Шамсоро, \& Мухидинов, 2012; Krzeminski, Prell, Busch-Stockfisch, Weiss, \& Hinrichs, 2014; O'Chiu \& Vardhanabhuti, 2017; Яценко, Ющенко, \& Пасичный, 2017). Эти вещества представляют собой макромолекулярные соединения, которые при определенном значении активной кислотности характеризуются противоположными зарядами. Белки проявляют полиамфолитную природу, в то время, как пектин относится к поликислотам. Взаимодействие противоположно заряженных веществ приводит к образованию электростатических, водородных и гидрофобных связей и формированию растворимых или нерастворимых белково-полисахаридных комплексов (O’Chiu \& Vardhanabhuti, 2017). Растворимость конъюгатов зависит от активной кислотности и соотношения белка и пектина (Толстогузов, 1987). Комплексы белок-полисахарид демонстрируют модифицированные функционально-технологические характеристики, проявляют стабилизирующие, эмульгирующие и другие свойства (Толстогузов, 1978). Исследования, посвященные взаимодействиям микропартикулированных белков и полисахаридов при получении и применении имитаторов жира, отсутствуют и представляют научный и практический интерес.

Цель работы - исследование взаимодействия микропартикулятов сывороточных белков и пектинов в составе комплексного имитатора жира в условиях формирования структуры ферментированного молочного продукта.

Для достижения поставленной цели были определены задачи исследования: 
- обосновать состав белково-полисахаридного имитатора жира для применения в производстве ферментированного молочного продукта;

- исследовать влияние комплексного имитатора жира на интенсивность кислотообразования и качество кисломолочного сгустка;

- разработать рецептуру и оценить качество ферментированного продукта с использованием комплексного имитатора жира.

Исследования были проведены в лаборатории кафедры технологии продуктов животного происхождения и центре коллективного пользования ФГБОУ ВО «Воронежский государственный университет инженерных технологий», а также лаборатории ООО «Моллаб».

\section{Материалы и методы исследований}

\section{Материалы}

В качестве объектов исследования рассматривали концентрат сывороточных белков, полученный на филиале «Калачеевский сырзавод» ПАО МК «Воронежский»; пектины высоко- и низкоэтерифицированный, приобретенные в торговой сети; образцы имитаторов жира, полученные на их основе; а также ферментированный продукт с использованием полученных имитаторов. В качестве технологически вспомогательных средств применяли заквасочные культуры Profiline YO 22.50 LOW OOО «Зеленые Линии», РФ, представляющие собой смесь термофильного стрептококка и болгарской палочки (Рябцева, Ганина, \& Панова, 2018).

\section{Методы и инструменты}

Пробы объектов исследования отбирали и подготавливали к анализам в соответствие со стандартом ISO 707-2013 «Молоко и молочные продукты. Руководство по отбору проб» ${ }^{1}$, органолептические показатели оценивали по стандарту ISO 22935-2:2009 Milk and milk products. Sensory analysis. Part 2: Recommended methods for sensory evaluation ${ }^{2}$. Показатели состава объектов исследования, их физико-химические свойства определяли в соответствии с Российскими нормативными документами. Массовую долю сухого вещества оценивали по потере массы в процентах при высушивании пробы продукта при постоянной температуре. Определение массовой доли белка проводили методом Кьельдаля, жира - кислотным методом. Активную кислотность определяли потенциометрическим методом, титруемую кислотность - титриметрическим ${ }^{3}$. Определение динамической вязкости осуществляли методом камертонной вибрации на вибровискозиметре SV-10 (Мельникова, Станиславская, \& Баранова, 2020). Микроструктуру объектов исследования оценивали с помощью бинокулярного микроскопа Альтами БИО 6. Для оценки размеров элементов микроструктуры объектов исследования применяли объект-микрометр.

\section{Процедура исследования}

Для получения белкового имитатора жира (микропартикулята) концентрат сывороточных белков растворяли в дистиллированной воде до массовой доли белка 8,6 \%. Далее раствор подвергали термомеханической обработке. Нагрев осуществляли до температуры $(87 \pm 2){ }^{\circ} \mathrm{C}$ с выдержкой 10 - 15 c. Механическое воздействие реализовали с помощью цифрового лабораторного гомогенизатора HG-15D-Set-A при скорости вращения ротора 15000 об/мин в течение 5 мин (Мельникова, 2020).

Отдельно готовили раствор пектина с массовой долей $5 \%$ : пектин растворяли в воде, нагретой до $50{ }^{\circ} \mathrm{C}$, диспергировали на лабораторном гомогенизаторе при скорости вращения ротора 18000 об/ мин в течение 6 - 7 мин (Krzeminski, Prell, BuschStockfisch, Weiss, \& Hinrichs, 2014).

Ферментированный десерт производили по технологии йогурта (Степанова, 2005). Обезжиренное молоко подвергали тепловой обработке при температуре $85-89^{\circ} \mathrm{C}$ с выдержкой $10-15$ мин, охлаждали до температуры $38-42{ }^{\circ} \mathrm{C}$. В молоко добавляли имитатор жира. Сквашивание проводили до формирования плотного сгустка кислотностью $85-90{ }^{\circ} \mathrm{T}$. В качестве контрольного образца для сравнения скорости кислотообразования и качества йогурта с имитатором жира был выбран классический продукт с массовой долей жира $3,5 \%$.

ГОСТ ISO 707-2013. (2013). Молоко и молочные продукты. М.: Стандартинформ.

2 ГОСТ Р ИСО 22935-2-2011. (2012). Молоко и молочные продукты. Органолептический аналич. Ч. 2. Рекомендуемые методы органолептической оценки. М.: Стандартинформ.

${ }^{3}$ Меркулова, Н. Г., Меркулов, М. Ю., \& Меркулов, И. Ю. (2017). Производственный контроль в молочной промышленности: Практическое руководство. СПб.: ГИОРД. 
В качестве имитатора жира рассматривали белковые и белково-полисахаридные системы, изготовленные в соответствии с Таблицей 1.

\section{Таблица 1}

Характеристика образцов имитатора жира

\begin{tabular}{|c|c|}
\hline $\begin{array}{l}\text { № об- } \\
\text { разца }\end{array}$ & Описание образца \\
\hline 1 & Микропартикулят сывороточных белков \\
\hline 2 & $\begin{array}{l}\text { Смесь микропартикулята сывороточных бел- } \\
\text { ков и раствора низкоэтерифицированно- } \\
\text { го пектина, взятых в соотношении } 1: 1\end{array}$ \\
\hline 3 & $\begin{array}{l}\text { Смесь микропартикулята сывороточных бел- } \\
\text { ков и раствора высокоэтерифицированно- } \\
\text { го пектина, взятых в соотношении } 1: 1\end{array}$ \\
\hline 4 & $\begin{array}{l}\text { Смесь растворов концентрата сывороточных бел- } \\
\text { ков и низкоэтерифицированного пектина, взятых } \\
\text { в соотношении } 1: 1 \text {, подвергнутая совместной тер- } \\
\text { момеханической обработке (микропартикуляции) }\end{array}$ \\
\hline 5 & $\begin{array}{l}\text { Смесь растворов концентрата сывороточ- } \\
\text { ных белков и высокоэтерифицированного } \\
\text { пектина, взятых в соотношении } 1: 1, \text { под- } \\
\text { вергнутая совместной термомеханиче- } \\
\text { ской обработке (микропартикуляции) }\end{array}$ \\
\hline
\end{tabular}

\section{Анализ данных}

Математическую обработку эксперимента проводили методами математической статистики по данным 5 - 10 опытов в трехкратной последовательности с помощью Statistica Base.

\section{Результаты и их обсуждение}

Полученные в соответствие с Таблицей 1 имитаторы жира характеризовались как однородная, в меру вязкая жидкость, от белого до светло-желтого цвета. Большое влияние на консистенцию имитаторов оказывала их вязкость и распределение частиц по размерам (Таблица 2).

Анализ микроструктуры имитаторов свидетельствовал о различии не только размеров частиц, но и их формы (Рисунок 1). Добавление пектина увеличивало значение их среднего диаметра. При этом меньший размер частиц у образцов № 2 и 3 в сравнении с образцами № 4 и 5 объяснялся низкой эффективностью взаимодействия частиц пектина и микропартикулята сывороточных белков. Стабильность компактной пространственной структуры частиц микропартикулята приводила к тому, что большая часть положительно заряженных групп белка взаимодействовали друг с другом еще на стадии денатурации и не могли впоследствии образовывать ионные пары с карбоксильными группами кислого полисахарида.

Таблица 2

Свойства образцов имитаторов жира

\begin{tabular}{ccc}
\hline $\begin{array}{c}\text { № об- } \\
\text { разца }\end{array}$ & \multicolumn{2}{c}{ Характеристика } \\
\cline { 2 - 3 } & $\begin{array}{c}\text { Средний } \\
\text { диаметр частиц, мкм }\end{array}$ & $\begin{array}{c}\text { Вязкость, мПа·с, } \\
\text { при темпера- } \\
\text { туре 20 }{ }^{\circ} \mathbf{C}\end{array}$ \\
\hline 1 & $2,0 \pm 0,1$ & $78,4 \pm 3,9$ \\
2 & $10,1 \pm 0,5$ & $325,0 \pm 16,2$ \\
3 & $6,2 \pm 0,3$ & $175,0 \pm 8,7$ \\
4 & $25,3 \pm 1,2$ & $524,0 \pm 26,2$ \\
5 & $17,0 \pm 0,8$ & $461,0 \pm 23,0$ \\
\hline
\end{tabular}

В ходе совместной тепловой обработки сывороточных концентратов и растворов полисахарида (образцы № 4 и 5) в результате денатурации белка увеличивалась «гибкость» полипептидной цепи, и возрастало число положительно заряженных групп, взаимодействующих с анионными группами пектина. Образующиеся связи способствовали формированию стерических пектиновых слоев вокруг белковых частиц, что способствовало формированию закрыто-упакованных молекул крупного размера. Образование гидрофобных белок-белковых взаимодействий внутри комплекса в ходе термической денатурации еще больше увеличивало размер частиц. Такие стабильные системы плохо разрушались последующей механической обработкой и характеризовались неправильной формой.

С целью исследования влияния имитаторов жира на динамику кислотообразования при сквашивании обезжиренного молока сначала рассматривали продукт с добавлением белкового имитатора (образец № 1). Его добавляли в количестве 5, 15, 25 и $35 \%$ от массы обезжиренного молока. Органолептически все образцы готового продукта при внесении от 5 до 25 \% имитатора характеризовались как однородные, в меру вязкие, с чистым кисломолочным вкусом и ароматом. Образец с массовой долей имитатора 35 \% отличался альбуминным привкусом и запахом. Добавление такого количества имитатора оказывало негативное влияние и на кислотность кисломолочного сгустка (Рисунок 2).

Вязкость продукта при повышении доли имитатора увеличивалась (Таблица 3). 

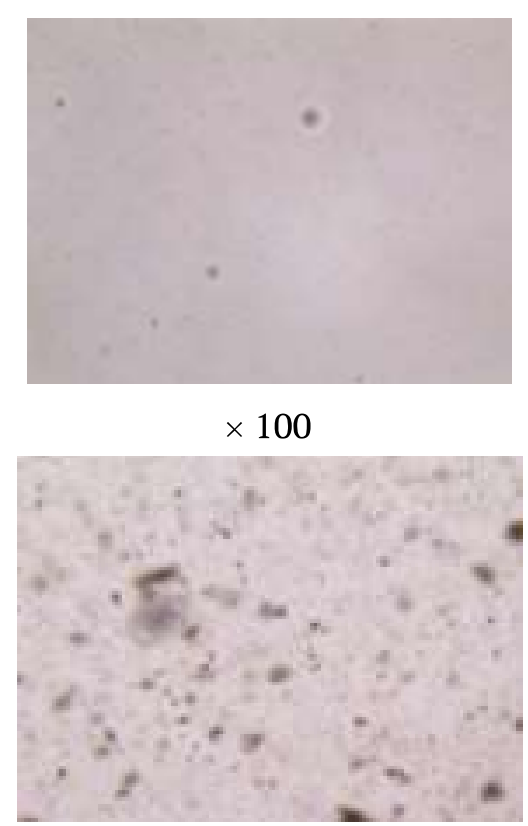

$\times 100$

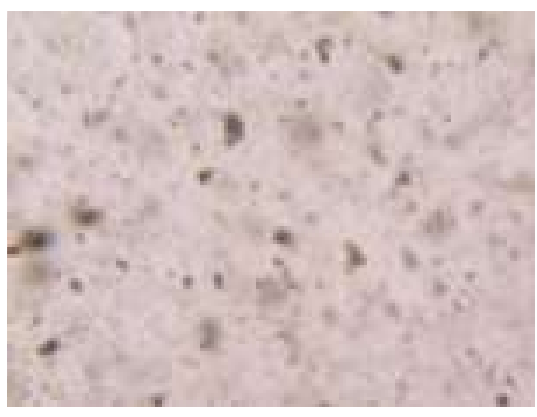

$\times 100$

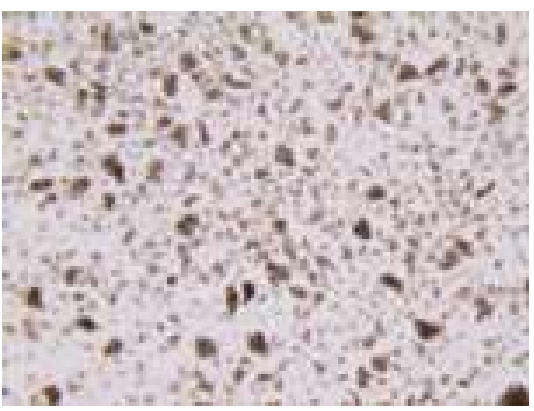

$\times 100$

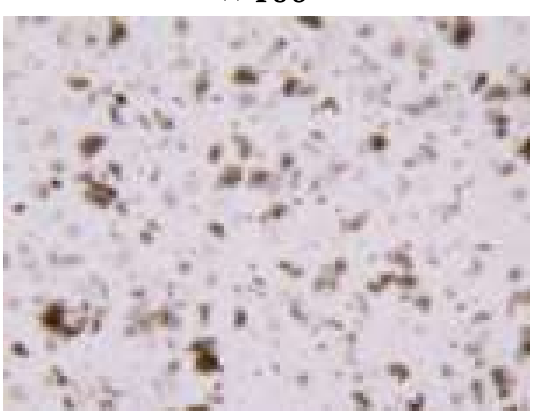

$\times 100$
Образец № 1

Образец № 2

Образец № 3

Образец № 4

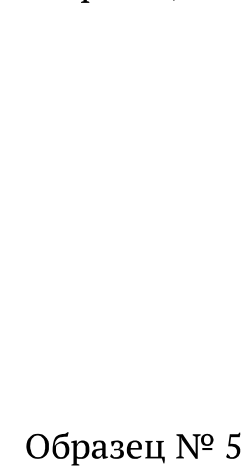

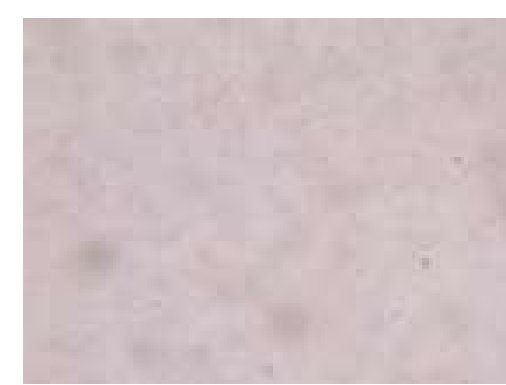

$\times 400$

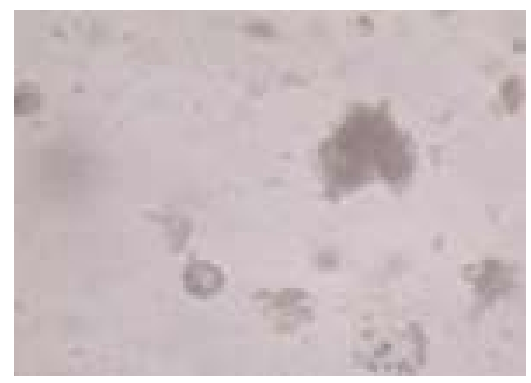

$\times 400$

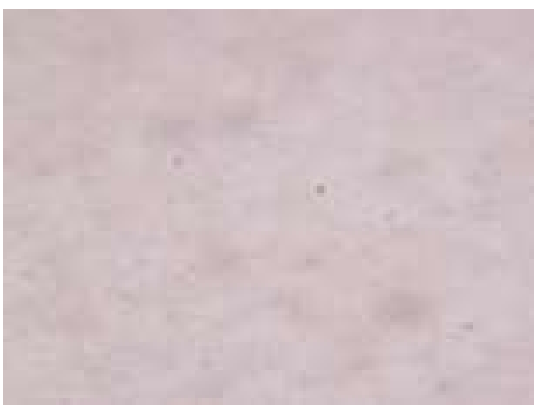

$\times 400$

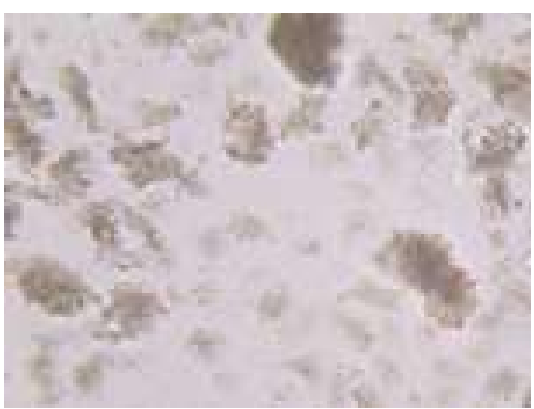

$\times 400$

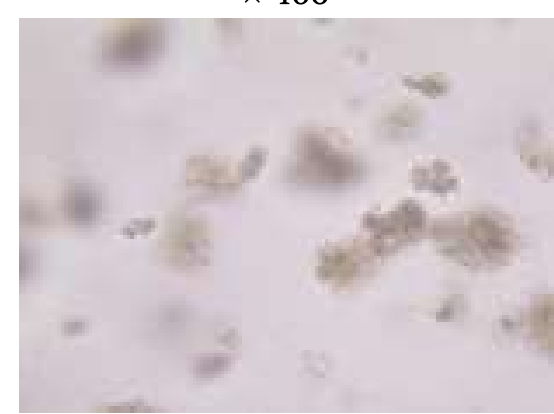

$\times 400$

Рисунок 1. Микроструктура образцов имитаторов жира 


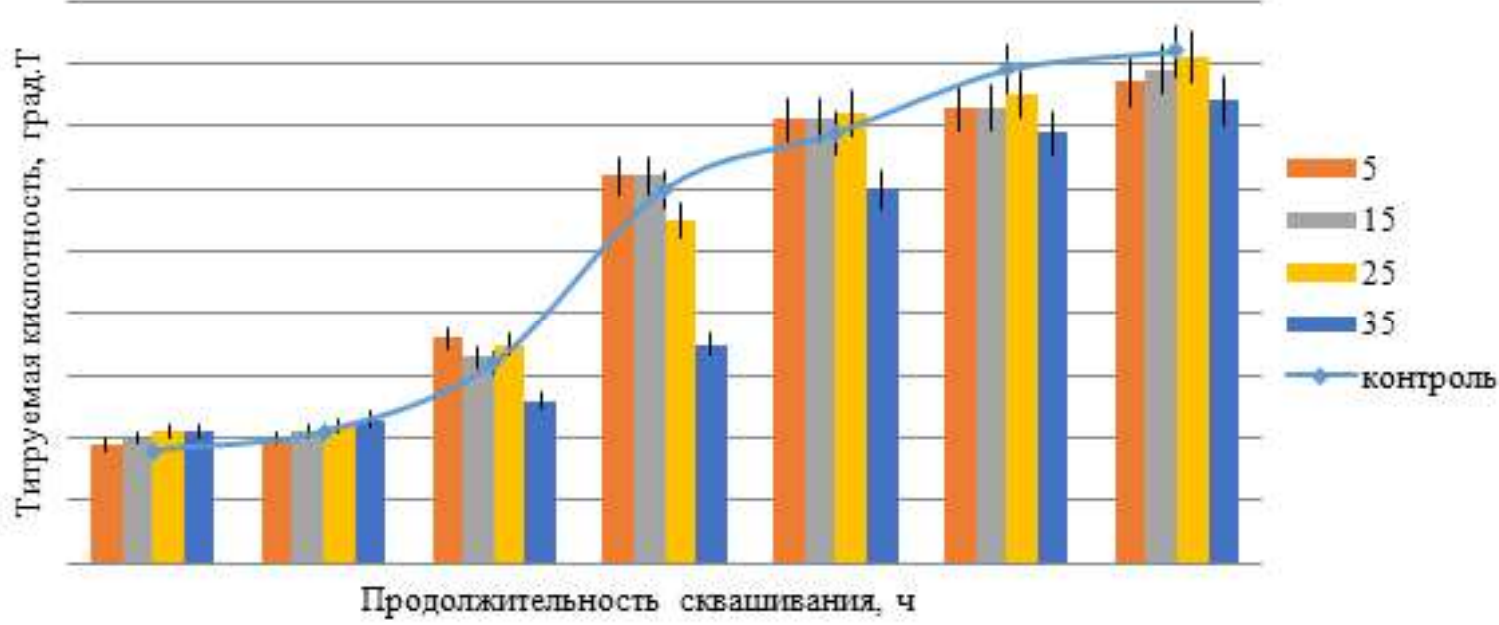

a)

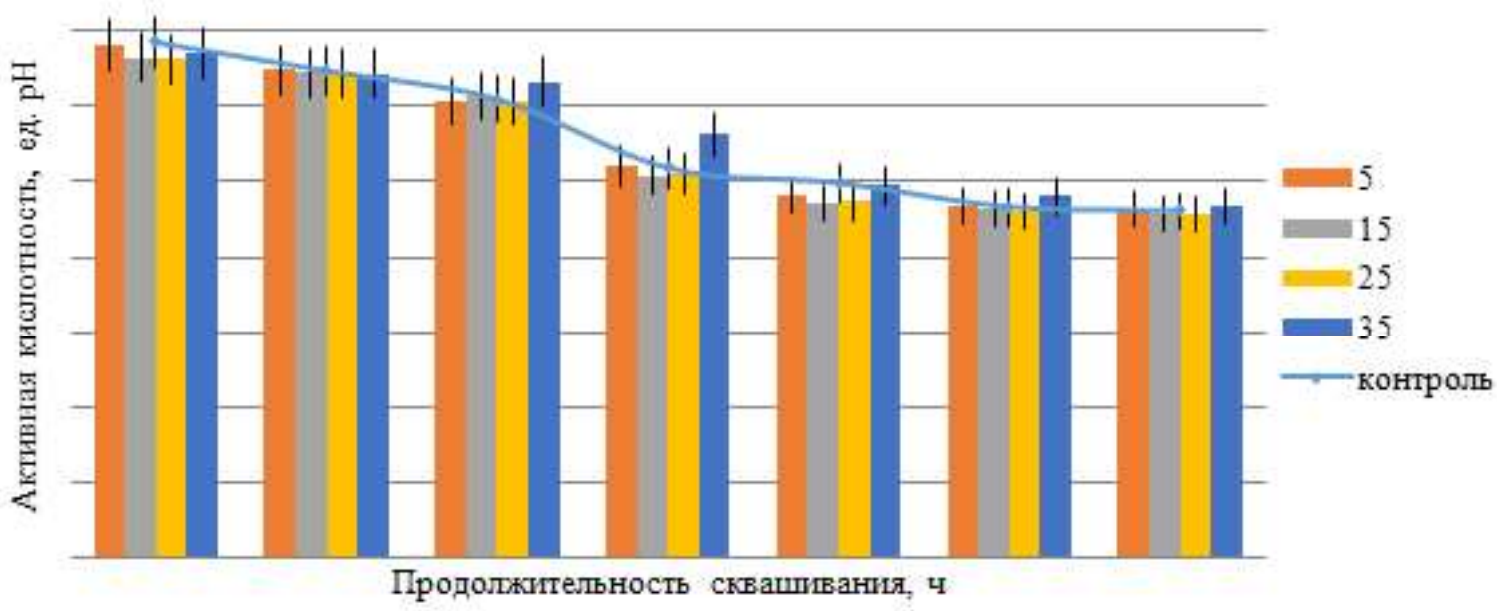

б)

Рисунок 2. Влияние доли белкового имитатора жира (образец № 1) на изменение титруемой (а) и активной (б) кислотности обезжиренного молока при сквашивании

В дальнейших исследованиях использовали $25 \%$ белкового имитатора в смеси с пектином. Сквашивание продукта с внесением имитаторов показало, что добавление пектина не оказывало существенного влияния на изменение титруемой и активной кислотности смеси. Внешне готовый продукт от- личался однородной гладкой консистенцией, отмечался чистый кисломолочный вкус и аромат.

Применение имитаторов жира оказывало существенное влияние на микроструктуру кислотного сгустка. В ходе гелеобразования происходила

Таблица 3

Вязкость образцов ферментированного продукта

\begin{tabular}{ccccc}
\hline \multicolumn{5}{c}{ Значение вязкости (мПа·с) для продукта с массовой долей белкового имитатора, \% } \\
\hline 0 (контроль) & 5 & 15 & 25 & 35 \\
$5,86 \pm 0,2$ & $6,17 \pm 0,3$ & $8,23 \pm 0,4$ & $9,63 \pm 0,4$ & $15,87 \pm 0,7$ \\
\hline
\end{tabular}


ассоциация казеиновых мицелл под действием ван-дер-ваальсовых сил притяжения, гидрофобного взаимодействия и водородных связей; образование структурированных цепочек, заполняющих весь объем молока и захватывающих как полостную, так и капиллярную воду. Частицы белкового имитатора (образец № 1) выполняли роль инертного наполнителя, располагаясь в ячейках кисломолочного сгустка так же, как это описано для жировых шариков (Тёпел, 2012; Горбатова, 2015).

Применение имитаторов № 4, 5 оказывало негативное влияние на характеристику кислотного сгустка. Крупные частицы белково-полисахарид- ных агрегатов «разрывали» сетчатую структуру, образованную казеиновыми мицеллами, обусловливая формирование слабого, рыхлого геля.

При внесении в продукт имитаторов № 2, 3 между молекулами казеина и карбоксильными группами пектина происходили взаимодействия с образованием пектино-казеиновых комплексов. В реакцию образования белково-полисахаридных агрегатов вовлекались и частицы денатурированного $\beta$-лактоглобулина. При этом создавались дополнительные инертные нити, прочно интегрированные в структуру сгустка. Это повышало прочность и вязкость готового продукта (Таблица 4), способствовало снижению синерезиса.

Таблица 4

Значение вязкости для ферментированного продукта с различной массовой долей пектина в составе комплексного имитатора жира

\begin{tabular}{|c|c|c|c|c|c|c|}
\hline \multirow[t]{2}{*}{ Пектин } & \multicolumn{6}{|c|}{ Значение вязкости (мПа·с) для продукта с массовой долей пектина, \% } \\
\hline & без пектина & $\mathbf{0 , 1}$ & $\mathbf{0 , 2}$ & 0,3 & $\mathbf{0 , 4}$ & 0,5 \\
\hline $\begin{array}{c}\text { Низкоэтерифицированный } \\
\text { (образец №2) }\end{array}$ & $9,63 \pm 0,4$ & $9,75 \pm 0,4$ & $16,3 \pm 0,8$ & $20,9 \pm 1,0$ & $44,5 \pm 2,2$ & $59,0 \pm 2,9$ \\
\hline $\begin{array}{c}\text { Высокоэтерифицированный } \\
\text { (образец № 3) }\end{array}$ & $9,63 \pm 0,4$ & $71,2 \pm 3,5$ & $86,1 \pm 4,3$ & $96,1 \pm 4,8$ & $85,9 \pm 4,2$ & $104,0 \pm 5,2$ \\
\hline $\begin{array}{c}\text { Низкоэтерифицированный } \\
\text { (образец № 4) }\end{array}$ & $9,63 \pm 0,4$ & $9,63 \pm 0,4$ & $9,75 \pm 0,4$ & $10,20 \pm 0,5$ & $15,23 \pm 0,7$ & $18,22 \pm 0,9$ \\
\hline $\begin{array}{c}\text { Высокоэтерифицированный } \\
\text { (образец № 4) }\end{array}$ & $9,63 \pm 0,4$ & $9,96 \pm 0,4$ & $11,35 \pm 0,5$ & $14,21 \pm 0,7$ & $19,02 \pm 0,9$ & $21,12 \pm 0,8$ \\
\hline
\end{tabular}

Выполненные исследования послужили основой для разработки рецептурно-компонентного решения и технологии ферментированного продукта. Готовый продукт предусматривает использование белково-полисахаридного имитатора жира, пред- ставляющего собой смесь микропартикулята сывороточных белков и высокоэтерифицированного пектина (образец № 3). Качественные показатели его отвечали требованиям нормативной документации (Таблица 5).

Таблица 5

Качественные показатели ферментированного продукта

\begin{tabular}{lc}
\hline \multicolumn{1}{c}{ Наименование показателя } & Значение показателя \\
\hline Внешний вид, консистенция & Однородная масса с глянцевой поверхностью, \\
Вкус и запах & хорошо удерживающая форму, консистенция сливочная \\
Цвет & Чистые, кисломолочные, без посторонних привкусов и запахов \\
Массовая доля жира, \% & Молочно-белый, равномерный по всей массе \\
Массовая доля белка, \% & 0,2 \\
Массовая доля СОМО, \% & 4,0 \\
Титруемая кислотность, ${ }^{\circ} \mathrm{T}$ & 9,0 \\
Содержание молочнокислых & 78,0 \\
микроорганизмов, КОЕ/г & $10^{7}$ \\
\hline
\end{tabular}


Энергетическая ценность продукта составила 32 ккал/100 г, что характеризует его как низкокалорийный.

\section{Выводы}

Выполненные исследования позволили обосновать состав белково-полисахаридного имитатора жира как пищевую композицию, полученную при смешивании микропартикулята сывороточных белков и высокоэтерифицированного пектина, для применения в рецептуре ферментированного молочного продукта. При этом наибольшую роль в формировании структуры продукта играла технология получения комплексного имитатора. Применение предложенного белково-полисахаридного имитатора жира не оказывало существенного влияния на интенсивность кислотообразования при сквашивании обезжиренного молока и позволило сформировать стойкую, сливочную консистенцию ферментированного продукта.

\section{Литература}

Артемова, Е. Н. (2001). Формирование пенных структур пищевых продуктов, содержащих белки и пектины. Известия ВУЗов. Пищевая технология, 4, 20-23.

Баранов, С. А., Евдокимов, И. А., Гордиенко, Л. А., \& Шрамко, М. И. (2020). Влияние микропартикулята сывороточных белков на показатели кисломолочных напитков. Молочная промышленность, 9, 59-62. https://doi.org/10.31515/10198946-2020-09-59-61

Горбатова, К. К. (2015). Биохимия молока и молочных продуктов. СПб.: ГИОРД.

Дымар, О. В. (2014). Технологические аспекты использования микропартикулятов сывороточных белков при производстве молочных продуктов. Молочная промышленность, 6, 19-21.

Евдокимов, И. А., Кравцов, В. А., Федорцов, Н. М., Богоровская, М. А., Бобрышева, Т. Н., Золоторева, М. С., \& Баранов, С. А. (2021). Состав и свойства микропартикулятов сывороточных белков. Молочная промышленность, 4, 40-44. https://doi.org/10.31515/1019-8946-2021-0440-44

Золотарева, М. С., Володин, Д. Н., Евдокимов, И. А., \& Харитонов, В. Д. (2018). Мембранные технологии для обеспечения эффективности и безопасности молочного производства. Молочная промышленность, 5, 36-39.

Куликова, В. В., Барыбина, Л. И., Оботурова, Н. П., \& Дацко, В. А. (2014). Комплексообразование концентрата сывороточных белков молока с анионными полисахаридами. Пищевая промышленность, 3, 62-64.

Мельникова, Е. И., \& Станиславская, Е. Б. (2017). Новые технологические решения в переработке творожной сыворотки. Исследование процесса микропартикуляции творожной сыворотки. Молочная промышленность, 1, 56-57.

Мельникова, Е. И., Станиславская, Е. Б., \& Баранова, К. Ю. (2020). Применение сывороточных белковых ингредиентов для получения имитаторов молочного жира. Вестник ВГУИТ, 82(3), 90-95.

Нечаев, А. П., Траубенберг, С. Е., Кочеткова, А. А., \& Колпакова, В. В. (2015). Пищевая химия. СПб.: ГИОРД.

Рябцева, С. А., Ганина, В. И., \& Панова, Н. М. (2018). Микробиология молока и молочных продуктов. СПб.: Лань.

Степанова, Л. И. (2005) Справочник технолога молочного производства. Технология и рецептуры. Том 1. Цельномолочные продукты. СПб.: ГИОРД.

Тёпел, А. (2012). Химия и физика молока. СПб.: Профессия.

Тешаев, Х. И., Усманова, С. Р., Шамсоро, О., \& Мухидинов, 3. К. (2012). Взаимодействие низкометилированных пектинов с концентратом белков молочной сыворотки. Вестник ВГУИТ, 1 , 158-164.

Толстогузов, В. Б. (1978). Искусственные продукты питания. Новый путь получения пищи и его перспективы. Научные основы производства. М.: Наука.

Толстогузов, В. Б. (1987). Новые формы белковой пищи: Технологические проблемы и перспективы производства. М.: Агропромиздат.

Яценко, О. В., Ющенко, Н. М., \& Пасичный, В. М. (2017). Исследование функционально-технологических свойств белково-полисахаридных комплексов и их использования в технологии масляных паст. Науковий вісник Львівського національного університету ветеринарної медицини та біотехнологій імені С. З. Гжицького, 19, 4549.

Di Cagno, R., De Pasquale, I., De Angelis, M., Buchin, S., Rizzello, C. G., \& Gobbetti, M. (2014). Use of microparticulated whey protein concentrate, exopolysaccharide-producing Streptococcus thermophilus, and adjunct cultures for making low-fat Italian Caciotta-type cheese. Journal of Dairy Science, 97(1), 72-84. https://doi.org/10.3168/ jds.2013-7078

Ipsen, R. (2017). Microparticulated whey proteins for improving dairy product texture. International Dairy Journal, 67, 73-79. https://doi.org/10.1016/j. idairyj.2016.08.009 
Krzeminski, A., Prell, K. A., Busch-Stockfisch, M., Weiss, J., \& Hinrichs, J. (2014). Whey proteinpectin complexes as new texturising elements in fat-reduced yoghurt systems. International Dairy Journal, 36(2), 118-127. https://doi.org/10.1016/j. idairyj.2014.01.018

Melnikova, E. I., Losev, A. N., \& Stanislavskaia, E. B. (2017). Microparticulation of caseic whey to use in fermented milk production. Foods and Raw Materials, 5(2), 83-93. https://doi. org/10.21603/2308-4057-2017-2-83-93

O’Chiu, E., \& Vardhanabhuti, B. (2017). Utilizing whey protein isolate and polysaccharide complexes to stabilize aerated dairy gels. Journal of Dairy Science, 100(5), 3404-3412. DOI: https://doi.org/10.3168/ jds.2016-12053

Olivares, M. L., Shahrivar, K., \& de Vicente, J. (2019). Soft lubrication characteristics of microparticulated whey proteins used as fat replacers in dairy systems.
Journal of Food Engineering, 245, 157-165. https:// doi.org/10.1016/j.jfoodeng.2018.10.015

Phil, K. (2019). Manufacture of whey protein products: Concentrates, isolate, whey protein fractions and microparticulated. In Whey Proteins. From Milk to Medicine (pp. 97-122). Academic Press. DOI: https:// doi.org/10.1016/B978-0-12-812124-5.00003-5

Torres, I. C., Amigo, J. M., Knudsen, J. C., Tolkach, A., Mikkelsen, B. Ø., \& Ipsen, R. (2018). Rheology and microstructure of low-fat yoghurt produced with whey protein microparticles as fat replacer. International Dairy Journal, 81, 62-71. https://doi. org/10.1016/j.idairyj.2018.01.004

Torres, I. C., Mutaf, G., Larsen, F. H., \& Ipsen, R. (2016). Effect of hydration of microparticulated whey protein ingredients on their gelling behaviour in a non-fat milk system. Journal of Food Engineering, 184, 31-37. https://doi.org/10.1016/j. jfoodeng.2016.03.018 


\title{
Protein-Polysaccharide Fat Imitator for Fermented Dairy
}

\author{
Elena I. Melnikova \\ Voronezh State University of Engineering Technology \\ 19, Revolutsii Prospect, Voronezh, 394036, Russian Federation \\ E-mail:melnikova@molvest.ru \\ Ekaterina B. Stanislavskaya \\ Voronezh State University of Engineering Technology \\ 19, Revolutsii Prospect, Voronezh, 394036, Russian Federation \\ E-mail: tereshkova-katia@yandex.ru \\ Arina R. Fedorova \\ Voronezh State University of Engineering Technology \\ 19, Revolutsii Prospect, Voronezh, 394036, Russian Federation \\ E-mail:arina.fiodorova@yandex.ru
}

\begin{abstract}
This paper describes studies that confirm the possibility of using a protein-polysaccharide fat simulator in a fermented dairy product. The aim of this work is to study the interaction of microparticulates of whey proteins and pectins in the composition of a complex fat simulator under conditions of the formation of the structure of a fermented dairy product. The indicators of the composition of the objects of study, their physical and chemical properties were determined in accordance with Russian standards. The addition of pectin increased the mean particle diameter and viscosity of the protein simulant fat. When mixing microparticulate whey proteins and pectin, the formation of particles of regular round shape with a diameter of 6.2 to $25.3 \mu \mathrm{m}$ was observed. Joint thermomechanical processing of whey protein concentrate and pectin solution contributed to the formation of larger particles of irregular shape. The use of proteinpolysaccharide fat imitators did not have a significant effect on the rate of acid formation during fermentation of skim milk. When a complex simulator, consisting of a mixture of microparticulate whey proteins and pectin, was introduced into the product, the particles of the protein component played the role of an inactive filler. Pectin participated in the formation of inert filaments firmly integrated into the clot structure. This increased the strength and toughness of the finished product, and reduced syneresis. The use of imitators obtained by thermomechanical processing of a mixture of whey protein concentrate and pectin solution had a negative effect on the characteristics of the acid clot. Large particles of protein-polysaccharide aggregates "broke" the network structure formed by casein micelles, causing the formation of a weak gel. The performed studies served as the basis for the development of a recipe-component solution and technology for a fermented product. Its quality indicators met the requirements of regulatory documents. The energy value of the new product was $32 \mathrm{kcal} / 100 \mathrm{~g}$, which characterizes it as a low-calorie product.
\end{abstract}

Keywords: microparticulation, pectin, fermented product, whey proteins, degree of esterification, microstructure, acid clot.

\section{References}

Artemova, E. N. (2001). Formirovanie pennykh struktur pishchevykh produktov, soderzhashchikh belki i pektiny [Formation of foam structures of food products containing proteins and pectins]. Izvestiya VUZov. Pishchevaya tekhnologiya [Proceedings of Universities. Food Technology], 4, 20-23.

Baranov, S. A., Evdokimov, I. A., Gordienko, L. A., \& Shramko, M. I. (2020). Vliyanie mikropartikulyata syvorotochnykh belkov na pokazateli kislomolochnykh napitkov [Influence of whey protein microparticulate on indicators of fermented milk drinks]. Molochnaya promyshlennost' [Dairy Industry], 9, 59-62. https://doi.org/10.31515/10198946-2020-09-59-61

Dymar, O. V. (2014). Tekhnologicheskie aspekty ispol'zovaniya mikropartikulyatov syvorotochnykh belkov pri proizvodstve molochnykh produktov [Technological aspects of the use of whey protein microparticulate in the production of dairy products]. Molochnaya promyshlennost' [Dairy Industry], 6, 19-21.

Evdokimov, I. A., Kravtsov, V. A., Fedortsov, N. M., Bogorovskaya, M. A., Bobrysheva, T. N., Zolotoreva, M. S., \& Baranov, S. A. (2021). Sostav i 
svoistva mikropartikulyatov syvorotochnykh belkov [Composition and properties of whey protein microparticulates]. Molochnaya promyshlennost' [Dairy Industry], 4, 40-44. https://doi. org/10.31515/1019-8946-2021-04-40-44

Gorbatova, K. K. (2015). Biokhimiya moloka i molochnykh produktov [Biochemistry of Milk and Dairy Products]. S-Petersburg: GIORD.

Kulikova, V. V., Barybina, L. I., Oboturova, N. P., \& Datsko, V. A. (2014). Kompleksoobrazovanie kontsentrata syvorotochnykh belkov moloka s anionnymi polisakharidami [Complexation of milk whey protein concentrate with anionic polysaccharides]. Pishchevaya promyshlennost' [Food Industry], 3, 62-64.

Mel'nikova, E. I., \& Stanislavskaya, E. B. (2017). Novye tekhnologicheskie resheniya $\mathrm{v}$ pererabotke tvorozhnoi syvorotki. Issledovanie protsessa mikropartikulyatsii tvorozhnoi syvorotki [New technological solutions in the processing of curd whey. Part 1. Investigation of the process of microparticulation of curd whey]. Molochnaya promyshlennost' [Dairy Industry], 1, 56-57.

Mel'nikova, E. I., Stanislavskaya, E. B., \& Baranova, K. $\mathrm{Yu}$. (2020). Primenenie syvorotochnykh belkovykh ingredientov dlya polucheniya imitatorov molochnogo zhira. Vestnik VGUIT [Voronezh State University of Engineering Technologies Bulletin], 82(3), 90-95.

Nechaev, A. P., Traubenberg, S. E., Kochetkova, A. A., \& Kolpakova, V. V. (2015). Pishchevaya khimiya [Food Chemistry]. S-Petersburg: GIORD.

Ryabtseva, S. A., Ganina, V. I., \& Panova, N. M. (2018). Mikrobiologiya moloka i molochnykh produktov [Microbiology of milk and dairy products]. S-Petersburg: Lan'.

Stepanova, L. I. (2005) Spravochnik tekhnologa molochnogo proizvodstva. Tekhnologiya i receptury. Tom 1 . Cel'nomolochnye produkty [Dairy production technologist's guide. Technology and recipes. Volume 1. Whole milk products.].S-Petersburg: GIORD.

Tepel, A. (2012). Khimiya i fizika moloka [Chemistry and Physics of Milk]. S-Petersburg: Professiya.

Teshaev, Kh. I., Usmanova, S. R., Shamsoro, O., \& Mukhidinov, Z. K. (2012). Vzaimodeistvie nizkometilirovannykh pektinov $\mathrm{s}$ kontsentratom belkov molochnoi syvorotki [Interaction of low methylated pectins with whey protein concentrate]. Vestnik VGUIT [Voronezh State University of Engineering Technologies Bulletin], 1, 158-164.

Tolstoguzov, V. B. (1978). Iskusstvennye produkty pitaniya. Novyi put' polucheniya pishchi i ego perspektivy. Nauchnye osnovy proizvodstva [Artificial food. A new way of getting food and its perspective. Scientific basis of production]. Moscow: Nauka.

Tolstoguzov, V. B. (1987). Novye formy belkovoi pishchi: Tekhnologicheskie problemy i perspektivy proiz- vodstva [New forms of protein food: Technological problems and production prospects]. Moscow: Agropromizdat.

Zolotareva, M. S., Volodin, D. N., Evdokimov, I. A., \& Kharitonov, V. D. (2018). Membrannye tekhnologii dlya obespecheniya effektivnosti i bezopasnosti molochnogo proizvodstva [Membrane technologies for efficient and safe dairy production]. Molochnaya promyshlennost' [Dairy Industry], 5, 3639.

YAcenko, O. V., YUshchenko, N. M., \& Pasichnyj, V. M. (2017). Issledovanie funkcional'no-tekhnologicheskih svojstv belkovo-polisaharidnyh kompleksov $\mathrm{i}$ ih ispol'zovaniya $\mathrm{v}$ tekhnologii maslyanyh past [Investigation of the functional and technological properties of protein-polysaccharide complexes and their use in the technology of oil pastes]. Naukovij visnik L'vivs'kogo nacional'nogo universitetu veterinarnoï medicini ta biotekhnologij imeni S.Z. Izhic kogo [Scientific Bulletin of Lviv National University of Veterinary Medicine and Biotechnology named after S.Z. Gzhytsky], 19, 45-49.

Di Cagno, R., De Pasquale, I., De Angelis, M., Buchin, S., Rizzello, C. G., \& Gobbetti, M. (2014). Use of microparticulated whey protein concentrate, exopolysaccharide-producing Streptococcus thermophilus, and adjunct cultures for making low-fat Italian Caciotta-type cheese. Journal of Dairy Science, 97(1), 72-84. DOI: https://doi. org/10.3168/jds.2013-7078

Krzeminski, A., Prell, K. A., Busch-Stockfisch, M., Weiss, J., \& Hinrichs, J. (2014). Whey protein-pectin complexes as new texturising elements in fat-reduced yoghurt systems. International Dairy Journal, 36(2), 118-127. https://doi.org/10.1016/j.idairyj.2014.01.018

Melnikova, E. I., Losev, A. N., \& Stanislavskaia, E. B. (2017). Microparticulation of caseic whey to use in fermented milk production. Foods and Raw Materials, 5(2), 83-93. https://doi. org/10.21603/2308-4057-2017-2-83-93

O'Chiu, E., \& Vardhanabhuti, B. (2017). Utilizing whey protein isolate and polysaccharide complexes to stabilize aerated dairy gels. Journal of Dairy Science, 100(5), 3404-3412. DOI: https://doi.org/10.3168/ jds.2016-12053

Olivares, M. L., Shahrivar, K., \& de Vicente, J. (2019). Soft lubrication characteristics of microparticulated whey proteins used as fat replacers in dairy systems. Journal of Food Engineering, 245, 157-165. https://doi.org/10.1016/j.jfoodeng.2018.10.015

Phil, K. (2019). Manufacture of whey protein products: Concentrates, isolate, whey protein fractions and microparticulated. In Whey Proteins. From Milk to Medicine (pp. 97-122). Academic Press. DOI: https:// doi.org/10.1016/B978-0-12-812124-5.00003-5 
Ipsen, R. (2017). Microparticulated whey proteins for improving dairy product texture. International Dairy Journal, 67, 73-79. https://doi.org/10.1016/j. idairyj.2016.08.009

Torres, I. C., Mutaf, G., Larsen, F. H., \& Ipsen, R. (2016). Effect of hydration of microparticulated whey protein ingredients on their gelling behaviour in a non-fat milk system. Journal of Food
Engineering, 184, 31-37. https://doi.org/10.1016/j. jfoodeng.2016.03.018

Torres, I. C., Amigo, J. M., Knudsen, J. C., Tolkach, A., Mikkelsen, B. Ø., \& Ipsen, R. (2018). Rheology and microstructure of low-fat yoghurt produced with whey protein microparticles as fat replacer. International Dairy Journal, 81, 62-71. https://doi. org/10.1016/j.idairyj.2018.01.004 